\title{
PENGGUNAAN SOFTWARE LINDO \\ DENGAN METODE PEMBELAJARAN PENEMUAN TERBIMBING \\ UNTUK MENINGKATKAN MOTIVASI BELAJAR MAHASISWA \\ MATEMATIKA ANGKATAN 2013 \\ PADA MATAKULIAH PROGRAM LINIER
}

\author{
Hastri Rosiyanti \\ Universitas Muhammadiyah Jakarta \\ hastrirosiyanti@yahoo.com
}

\begin{abstract}
Abstrak
Dalam matakuliah Program Linier peneliti melakukan penelitian tindakakan kelas untuk meningkatkan motivasi belajar mahasiswa angkatan 2013 dengan menggunakan metode pembelajaran penemuan terbimbing berbantuan software LINDO. Program Linier adalah metode matematik dalam mengalokasikan sumberdaya yang langka untuk mencapai tujuan tunggal seperti memaksimumkan keuntungan atau meminimumkan biaya. Metode penemuan terbimbing merupakan metode pengembangan dari Teori Konstruktivisme Pieget yaitu pembelajaran yang menekankan pentingnya kegiatan mahasiswa yang aktif dalam mengkonstruksikan pengetahuannya sendiri. Secara umum, software LINDO akan menyediakan pengalaman langsung kepada mahasiswa dalam belajar merumuskan, menyelesaikan serta menaksir kebenaran dan kelayakan rumus berdasarkan penyelesaiannya. Secara umum terjadi peningkatan motivasi belajar mahasiswa sebesar $2,82 \%$ dari siklus I $(69,46 \%)$ ke siklus II $(72,28 \%)$ dan sebesar 2,83\% dari siklus II $(72,28 \%)$ ke siklus III $(75,11 \%)$. Motivasi belajar mahasiswa pada matakuliah program linier dengan metode pembelajaran penemuan terbimbing berbantuan software LINDO telah mencapai $75,11 \%$ dengan kategori tinggi. Lebih lanjut mahasiswa menyukai pembelajaran penemuan terbimbing dengan software LINDO dengan hasil persentasi 93,75\%.
\end{abstract}

Kata Kunci: Software LINDO, Metode Penemuan Terbimbing, Program Linier, Pendidikan Matematika

\section{PENDAHULUAN}

Program Linier adalah metode matematik dalam mengalokasikan sumberdaya yang langka untuk mencapai tujuan tunggal seperti memaksimumkan keuntungan atau meminimumkan biaya. Program linier banyak diterapkan dalam membantu menyelesaikan 
masalah ekonomi, industri, militer, sosial dan lain-lain. Dalam kehidupan sehari-hari kita sering menggunakan prinsip-prinsip pada program linier yang tanpa didasari seperti pada proyek bangunan gedung, pemakaian tanah untuk lahan parkir, dan lain-lain. Matakuliah program linier perlu diberikan kepada semua mahasiswa pendidikan Matematika untuk membekali mahasiswa dalam menyelesaikan berbagai permasalahan dengan pengetahuan yang dimilikinya dan mengaplikasinya dalam dunia nyata, seperti masalah ekonomi, industri militer, sosil dan lain-lain.

Dalam pembelajaran program linier di kampus, dosen hendaknya memilih dan menggunakan strategi yang banyak melibatkan mahasiswa aktif dalam belajar, seperti mahasiswa dapat mengamati, mengaplikasikan, mampu menjawab pertanyaan dan berdiskusi. Pada proses pembelajaran dosen mengupayakan suasana belajar menjadi lebih kondusif dan mahasiswa lebih dominan dalam kegiatan belajar mengajar.

Berdasarkan hasil observasi peneliti pada mahasiswa pendidikan Matematika angkatan 2013 FIP UMJ Cirendeu, didapatkan fakta bahwa masih terdapat mahasiswa yang mendapatkan nilai E pada matakuliah di Matematika, yaitu Aljabar Linier. Beberapa mahasiswa terlihat belum termotivasi untuk memperhatikan penjelasan dosen dan mengikuti pembelajaran yang dilaksanakan oleh dosen. Pembelajaran masih berpusat pada dosen, sehingga mahasiswa terkesan menunggu materi yang diberikan.

Di dalam pandangan Bruner, belajar dengan penemuan adalah belajar untuk menemukan, dimana seorang peserta didik dihadapkan dengan suatu masalah atau situasi yang tampaknya ganjil sehingga peserta didik dapat mencari jalan pemecahan (Markaban, 2006: 9). Metode ini memungkinkan mahasiswa untuk aktif dalam menemukan konsepkonsep pengetahuan program linier dengan bantuan bimbingan dosen.

Selain penggunaan metode pembelajaran yang tepat, motivasi belajar juga dipengaruhi oleh media yang digunakan. Agar tujuan pendidikan dapat tercapai, maka perlu diperhatikan segala sesuatu yang mendukung keberhasilan program pendidikan tersebut. Dari sekian faktor penunjang keberhasilan tujuan pendidikan, kesuksesan dalam proses pembelajaran merupakan salah satu faktor yang sangat dominan. Diperlukan sekali dalam proses pembelajaran diciptakan suasana yang kondusif, agar mahasiswa benar-benar tertarik dan ikut aktif dalam proses tersebut. Media merupakan salah satu faktor yang turut mendukung keberhasilan pembelajaran agar suasana pembelajaran menjadi kondusif.

Media pembelajaran sangat beraneka ragam, dan hampir semua bermanfaat. Cukup banyak jenis dan bentuk media yang telah dikenal, salah satunya adalah komputer. Komputer merupakan salah satu media yang masih populer dikalangan mahasiswa yang dapat membuat 
pembelajaran menarik. Penyelesaian masalah program linear dengan banyak variabel akan lebih mudah dengan menggunakan program komputer. Dengan berkembangnya teknologi komputer, maka bermunculan pula perangkat lunak (software) yang dapat digunakan untuk menyelesaikan masalah program linier. Perangkat lunak ini dibuat dengan tujuan untuk membantu mahasiswa dalam mempermudah menyelesaikan masalah atau pekerjaannya. Untuk keperluan penyelesaian program linear sudah tersedia beberapa program khusus.

Salah satu aplikasi komputer yang dapat digunakan belajar program linier adalah software LINDO (Linear INteractive Discrete Optimizer). Software ini dapat menyelesaikan permasalahan program linier dengan mudah, cepat dan akurat bahkan mampu menyelesaikan masalah program linier sampai 100 constraints (fungsi kendala) dengan 200. Prinsip kerja yang utama dari program LINDO adalah memasukkan rumus, menyelesaikannya serta menaksir kebenaran dan kelayakan rumus berdasarkan penyelesaiannya. Rumus yang dimaksud di sini adalah dalam bentuk Matematika. Permasalahan ini mampu dipecahkan dengan program linear menggunakan program softwware LINDO. Secara umum, software LINDO akan menyediakan pengalaman langsung kepada mahasiswa dalam belajar merumuskan, menyelesaikan serta menaksir kebenaran dan kelayakan rumus berdasarkan penyelesaiannya. Dengan demikian, software LINDO mendukung kegiatan penemuan dan dapat memotivasi mahasiswa dalam belajar program linier.

Adapun penelitian yang telah dilakukan oleh peneliti lain, yaitu Rahmy Zulmaulida dan Edy Saputra dengan judul pengembnagan bahan ajar program linier berbantuan LINDO Software, dengan hasil penelitiannya adalah dengan menggunakan software ini memungkinkan perhitungan masalah pemrograman linear dengan $n$ variabel. Prinsip kerja utama Lindo adalah memasukkan data, menyelesaikan, serta menaksirkan kebenaran dan kelayakan data berdasarkan penyelesaiannya.

Berdasarkan masalah yang dipaparkan dan alternatif metode yang ada, maka peneliti akan menggunakan software LINDO dengan metode penemuan terbimbing pada matakuliah program linier dalam penelitian ini. Dalam penelitian ini, peneliti berharap dengan menggunakan software LINDO dengan metode penemuan terbimbing dapat meningkatkan motivasi belajar pada matakuliah Program Linier. Adapun perumusan masalah dalam penelitian ini adalah (1) Bagaimana sikap mahasiswa terhadap pembelajaran dengan penggunaan software LINDO dengan metode penemuan terbimbing pada matakuliah Program Linier? (2) Bagaimanakah motivasi belajar mahasiswa semester V setelah mengikuti pembelajaran dengan penggunaan software LINDO dengan metode penemuan terbimbing pada matakuliah Program Linier? 
Istilah motivasi berasal dari kata motif yang dapat diartikan sebagai kekuatan yang terdapat dalam diri individu, yang menyebabkan individu tersebut bertindak atau berbuat. Motif atau motive adalah dorongan yang terarah kepada pemenuhan kebutuhan psikis atau rokhaniah (Sukmadinata, 2007: 61). Motif adalah keadaan dalam pribadi orang yang mendorong individu untuk melakukan aktivitas-aktivitas tertentu guna mencapai sesuatu tujuan (Suryabrata, 2005: 70). Jadi, motif bukanlah hal yang dapat diamati, tetapi adalah hal yang dapat disimpulkan adanya karena sesuatu yang dapat kita saksikan.

Motivasi belajar matematika adalah suatu usaha yang disadari untuk menggerakan, mengarahkan dan menjaga perilaku mahasiswa agar terdorong untuk melakukan aktivitas belajar matematika sehingga mencapai hasil belajar matematika yang maksimal. Indikator dari motivasi belajar yang peneliti ambil adalah (1) Tekun dalam menghadapi tugas, (2) Ulet dalam menghadapi kesulitan, (3) Menunjukkan minat, (4) Senang bekerja mandiri, (5) Cepat bosan pada tugas- tugas rutin, (6) Dapat mempertahankan pendapatnya, (7) Tidak mudah melepas hal yang diyakini itu dan (8) Senang mencari dan memecahkan masalah soal-soal.

Dilihat dari jenisnya, media dibagi ke dalam media audio, visual dan media audiovisual. Media audio adalah media yang hanya mengandalkan kemampuan suara saja, seperti radio, cassete recorder, piringan hitam. Media visual adalah media yang hanya mengandalkan indera penglihatan. Media visual ini ada yang menampilkan gambar atau simbol yang bergerak seperti film strip (film rangkai), foto, gambar atau lukisan, cetakan. Ada pula media visual yang menampilkan gambar atau simbol yang bergerak seperti film bisu, film kartun. Sedangkan media audio visual merupakan media yang mempunyai unsur suara dan unsur gambar (Sutikno, 2009: 109).

Media jika dipahami secara garis besar adalah manusia, materi atau kejadian yang membangun kondisi yang membuat mahasiswa mampu memperoleh pengetahuan, keterampilan atau sikap. Media sebagai sesuatu yang dapat membawa informasi dan pengetahuan dalam interaksi yang berlangsung antara peneliti dengan mahasiswa. Dalam penelitian ini peniliti menggunakan jenisny media visual, yaitu software LINDO.

LINDO (Linear Interactive Discrete Optimizer) merupakan salah satu perangkat lunak (software) komputer. Kegunaan utama program ini adalah untuk memasukkan rumusan program linear dengan cepat, menyelesaikannya, dan menetapkan perbaikan atau pengecekan rumusan dasar pada penyelesaian. Menu utama pada LINDO yaitu: File, Edit, Solve, Report, Window, Help. Pemilihan menu utama pada LINDO dapat dilakukan dengan menekan Alt + $\mathrm{F}$, Alt $+\mathrm{E}$, Alt $+\mathrm{S}$, Alt $+\mathrm{R}$, Alt $+\mathrm{W}$, Alt $+\mathrm{H}$ atau sorot dengan mouse lalu tekan klik pada icon yang disorot tersebut. 


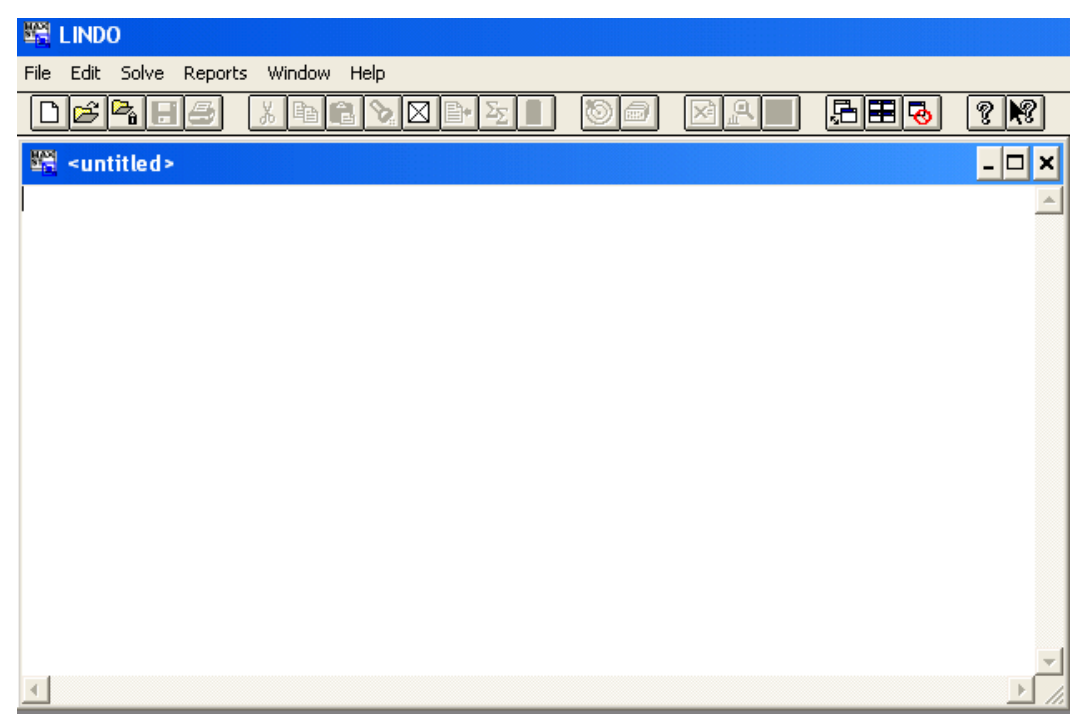

Gambar 1. Tampilan Software LINDO

Berdasarkan kajian tentang software LINDO dan metode penemuan terbimbing, maka dapat disimpulkan prosedur yang dilakukan oleh peneliti dalam penelitian ini, yaitu:

a. Merumuskan dan menyusun masalah yang akan diberikan kepada peserta didik dalam bentuk file-file LINDO dan LKM dengan jelas.

b. File-file LINDO yang diberikan peneliti akan ditampilkan di setiap laptop mahasiswa. Mahasiswa diminta menyusun, memproses dan menganalisis data-data tersebut dengan bantuan bimbingan peneliti dan Lembar Kerja Mahasiswa.

c. Mahasiswa diminta menyusun konjektur (prakiraan) dari hasil analisis yang dilakukannya.

d. Peneliti berkeliling mengontrol mahasiswa dan memberi bimbingan sehingga pembelajaran sesuai dengan arah dan tujuan yang hendak dicapai.

e. Mahasiswa diminta menyimpulkan konjektur dengan bahasa mereka sendiri. Penyimpulan konjektur dapat dilakukan dengan persentasi hasil analisis.

f. Peneliti menyediakan soal latihan atau soal tambahan untuk memeriksa apakah hasil penemuan itu benar sebagai sarana evaluasi.

\section{METODE PENELITIAN}

Penelitian ini merupakan Penelitian Tindakan Kelas (Classroom Action Research). Penelitian Tindakan Kelas ini merupakan penelitian tindakan yang dilakukan untuk meningkatkan motivasi belajar mahasiswa dengan menggunakan bantuan software LINDO melalui metode pembelajaran penemuan terbimbing pada matakuliah Program Linier. Desain penelitian ini mengacu pada proses pelaksanaan penelitian tindakan kelas model 
Kemmis\&Taggart dengan tahapan menyusun perencanaan tindakan (action plan), pelaksanaan tindakan (actuating), pengamatan (observing), dan refleksi (reflecting).

Penelitian ini dilaksanakan pada bulan Juli-Desember 2015 di FIP Universitas Muhammadiyah Jakarta yang beralamatkan J1.KH.Ahmad Dahlan Cirendeu, Ciputat 15419. Subjek penelitian ini adalah mahasiswa angkatan 2013 Pendidikan Matematika FIP UMJ. Objek penelitian ini adalah keseluruhan proses pada penerapan model penggunaan software LINDO dengan metode penemuan terbimbing pada matakuliah program linier. Setting penelitian ini menggunakan setting kelas, yaitu mengamati pelaksanaan pembelajaran yang meliputi aktivitas mahasiswa dalam pembelajaran matematika. Pelaksanaan penelitian dan pengambilan data diperoleh pada saat proses kegiatan pembelajaran berlangsung di dalam kelas.

Metode pengumpulan data yang digunakan dalam penelitian ini adalah sebagai berikut: (1) Metode Observasi: Berkaitan dengan teknik pengumpulan data yang digunakan tersebut, maka instrumen pengumpulan data yang digunakan dalam metode observasi meliputi: catatan lapangan, pedoman wawancara, dan foto-foto. (2) Angket: Dalam penelitian ini angket yang digunakan adalah angket motivasi belajar, sehingga pernyataan-pernyataan yang disusun berdasarkan aspek-aspek motivasi belajar. Teknik angket dilaksanakan setiap akhir siklus dan digunakan untuk mencapai indikator keberhasilan.

\section{HASIL DAN PEMBAHASAN}

Adapun langkah-langkah yang dilakukan setelah tindakan pra PTK terdiri atas beberapa siklus/daur yaitu:

\section{Siklus I}

a. Perencanaan. (1) Pembuatan SAP, (2) Mempersiapkan sarana laptop dan software LINDO yang akan digunakan dalam pembelajaran, (3) Mempersiapkan LKM, (4) Mempersiapkan lembar angket motivasi belajar, (5) Menyusun lembar wawancara, (6) mempersiapkan lembar kosong untuk catatan lapangan, dan (7) Mempersiapkan kamera.

b. Tindakan. Setelah perencanaan dirasa cukup matang dan ideal, peneliti kemudian melaksanakan rencana penelitian yang telah disusun. Pelaksanaan diusahakan sebaik mungkin agar sesuai apa yang direncanakan. Adapun tindakan-tindakan yang dilakukan meliputi: (1) Peneliti melaksanakan metode pembelajaran penemuan terbimbing dengan bantuan software LINDO. (2) Peneliti mengobservasi proses pembelajaran yang sedang 
berlangsung. (3) Peneliti membagikan LKM pada setiap mahasiswa pada proses pembelajaran.

c. Observasi. Dalam pemantauan itu, dilakukan pencatatan-pencatatan sesuai dengan lembar yang telah disiapkan yaitu catatan lapangan. Untuk memperoleh data yang lebih obyektif, kegiatan observasi juga menggunakan alat-alat optik atau elektronik, seperti kamera digital.

d. Refleksi. Refleksi dilakukan setelah tindakan dan observasi. Kegiatan refleksi menghasilkan data yang diperoleh selama observasi, kemudian data itu dikumpulkan, direduksi, dianalisis dan disimpulkan. Data itu berupa data lembar wawancara, lembar angket motivasi, catatan lapangan dan data dokumentasi. Hasil refleksi digunakan untuk menentukan langkah-langkah lebih lanjut dalam upaya mencapai indikator keberhasilan.

\section{Siklus II}

Siklus kedua dilakukan seperti tahap pada siklus pertama. Siklus kedua disusun berdasarkan refleksi pada siklus pertama. Kegiatan pada siklus kedua dimaksudkan sebagai penyempurnaan terhadap pelaksanaan pada siklus pertama. Bila pada siklus kedua telah tercapai indikator keberhasilan dan peneliti merasa cukup, maka siklus selanjutnya tidak perlu dilakukan. Jika belum tercapai pada siklus kedua, maka PTK akan dilanjutkan pada siklus berikutnya melalui tahap-tahap yang sama dengan siklus sebelumnya sampai tercapai indikator keberhasilan.

Hasil penelitian ini menunjukkan peningkatan motivasi belajar mahasiswa angkatan 2013 Pendidikan Matematika FIP UMJ pada matakuliah Program Linier setelah tiga siklus dilaksanakan pembelajaran penemuan terbimbing dengan penggunaan software LINDO.

Tabel 1. Perbandingan Motivasi Belajar Mahasiswa Angkatan 2013 Pendidikan Matematika FIP UMJ

\begin{tabular}{|c|l|c|c|c|c|c|c|}
\hline \multirow{2}{*}{ No Indikator } & \multicolumn{2}{|c|}{ Siklus 1 } & \multicolumn{2}{c|}{ Siklus 2 } & \multicolumn{2}{c|}{ Siklus 3 } \\
\cline { 3 - 8 } & & $\mathbf{\%}$ & Ket & \% & Ket & \% & Ket \\
\hline 1 & $\begin{array}{l}\text { Tekun dalam menghadapi } \\
\text { kesulitan }\end{array}$ & 70,59 & Sedang & 72,06 & Sedang & 75,00 & Tinggi \\
\hline 2 & $\begin{array}{l}\text { Ulet dalam menghadapi } \\
\text { kesulitan }\end{array}$ & 75,00 & Tinggi & 78,53 & Tinggi & 80,00 & Tinggi \\
\hline 3 & Menunjukkan minat & 68,82 & Sedang & 72,65 & Sedang & 75,00 & Tinggi \\
\hline 4 & Senang bekerja mandiri & 66,27 & Sedang & 70,98 & Sedang & 75,29 & Tinggi \\
\hline 5 & $\begin{array}{l}\text { Cepat bosan pada tugas-tugas } \\
\text { rutin }\end{array}$ & 73,53 & Sedang & 73,53 & Sedang & 73,53 & Sedang \\
\hline 6 & $\begin{array}{l}\text { Dapat mempertahankan } \\
\text { pendapatnya }\end{array}$ & 66,67 & Sedang & 69,41 & Sedang & 72,94 & Sedang \\
\hline 7 & $\begin{array}{l}\text { Tidak mudah melepas hal yang } \\
\text { diyakini itu }\end{array}$ & 70,59 & Sedang & 71,76 & Sedang & 73,53 & Sedang \\
\hline
\end{tabular}




\begin{tabular}{|c|l|c|c|c|c|c|c|}
\hline 8 & $\begin{array}{l}\text { Senang mencari dan } \\
\text { memecahkan masalah soal-soal }\end{array}$ & 63,92 & Sedang & 67,45 & Sedang & 72,94 & Sedang \\
\hline
\end{tabular}

Wawancara dilakukan setiap akhir siklus. Pada siklus I ada 2 mahasiswa yang menjadi narasumber, yaitu mahasiswa yang memiliki nilai angket terendah dan tertinggi dengan hasil persentasinya adalah $\frac{87,5+75}{2}=81,25 \%$ Pada siklus II ada 2 mahasiswa yang menjadi narasumber, yaitu mahasiswa yang memiliki nilai angket terendah dan tertinggi dengan hasil persentasinya adalah $\frac{87,5+100}{2}=93,75 \%$. Pada siklus III ada 2 mahasiswa yang menjadi narasumber, yaitu mahasiswa yang memiliki nilai angket terendah dan tertinggi dengan hasil persentasinya adalah $\frac{87,5+100}{2}=93,75 \%$.

Berdasarkan pendapat ahli mengenai metode penemuam terbimbing bahwa motivasi mahasiswa matemtika angkatan 2013 terlihat adanya peningkatan di setiap siklus, hal ini dikarenakan mahasiswa dituntut untuk mencari jalan pemecahan masalahnya sendiri dengan berbantuan software LINDO.

\section{SIMPULAN DAN SARAN}

Secara umum terjadi peningkatan motivasi belajar mahasiswa sebesar 2,82\% dari siklus I $(69,46 \%)$ ke siklus II $(72,28 \%)$ dan sebesar $2,83 \%$ dari siklus II $(72,28 \%)$ ke siklus III (75,11\%). Motivasi belajar mahasiswa pada matakuliah program linier dengan metode pembelajaran penemuan terbimbing berbantuan software LINDO telah mencapai $75,11 \%$ dengan kategori tinggi. Lebih lanjut mahasiswa menyukai pembelajaran penemuan terbimbing dengan software LINDO dengan hasil persentasi 93,75\%.

Setelah melakukan penelitian ini, peneliti memiliki beberapa saran untuk meningkatkan pembelajaran yaitu:

1. Dosen hendaknya melakukan variasi metode pembelajaran dalam mengajar mahsiswa agar mahasiswa termotivasi untuk belajar

2. Software LINDO dapat menjadi salah satu alternatif software untuk digunakan dalam pembelajaran khususnya pada mata kuliah program linier. 


\section{DAFTAR PUSTAKA}

Markaban. (2006). Model pembelajaran Matematika Dengan Pendekatan Penemuan Terbimbing. Yogyakarta: Departemen Pendidikan Nasional Pusat Pengembangan dan Penatran Guru Matematika.

Sukmadinata, Nana Syaodih. (2007). Landasan Psikologi Proses Pendidikan. Bandung: PT Remaja Rosdakarya.

Suryabrata, Sumadi. (2005). Psikologi Pendidikan. Jakarta: PT Raja Grafindo Persada.

Sutikno, Sobry. (2009). Belajar dan Pembelajaran Upaya Kreatif dalam Mewujudkan Pembelajaran yang Berhasil. Bandung: Prospect. 